\title{
Letter to the Editor: A response to Chessa et al. (2018)
}

\author{
P. Plaisancié, ${ }^{* 1}$ J. Bruno, ${ }^{*} †$ A. Nicolas,ł S. Pesenti, ${ }^{*}$ J. Schwarz,† J.-L. Simon,† and J. Léonilł \\ *Univ-Lyon, CarMeN laboratory, INRA U1397, Inserm U1060, Université Claude Bernard Lyon 1, INSA Lyon, F-69621 Villeurbanne, France \\ †INGREDIA SA, F-62000, Arras, France \\ fINRA, UMR1253 Science et Technologie du Lait et de l'œEuf, Agrocampus Ouest, F-35000 Rennes, France
}

We thank the editor-in-chief for the opportunity to respond to the letter by Chessa et al. (2018) in this issue regarding our paper in the Journal of Dairy Science (Bruno et al., 2017). First, we thank Stephania Chessa, Omar Bulgari, and Anna Caroli for the great vigilance taken in regards to the nomenclature of $\beta$-casein variants. We have indeed identified the sequences of genetic variants of $\beta$-casein using the Swiss-PROT database (http://www.uniprot.org/uniprot/P02666). Unfortunately, this database has not been updated with the works of Farrell et al. (2004), Caroli et al. (2009), and Gallinat et al. (2013). It was from this database that we identified the sequences of fragment $94-123$ of the $\beta$-casein variants to be chemically synthesized as part of our structure-function relationship study. The sequence corrections subsequently made from the cDNA by Gallinat et al. (2013) having invalidated the amino acid substitution at position 117 (Gln instead of Glu), we fully agree that the $\beta$-casofensin sequences of the $\mathrm{A}^{1}$, $\mathrm{A}^{2}$, and $\mathrm{G}$ variants of $\beta$-casein are identical.

Consequently, we regret these errors in our published paper and correct the errors in a corrigendum in this issue (Bruno et al., 2018). In this corrigendum, the $\beta$-casofensin variant $\mathrm{A} 1$ will be called $\beta$-casofensin variant $\mathrm{A} 1-\mathrm{Gln}_{117}$ (or $\beta$-casofensin $\mathrm{A} 2-\mathrm{Gln}_{117}$ ), meaning that the sequence synthesized in our study has a Gln in position 117, not a Glu.

\section{REFERENCES}

Bruno, J., A. Nicolas, S. Pesenti, J. Schwarz, J.-L. Simon, J. Léonil, and P. Plaisancié. 2017. Variants of $\beta$-casofensin, a bioactive milk peptide, differently modulate the intestinal barrier: In vivo and ex vivo studies in rats. J. Dairy Sci. 100:3360-3372. https://doi.org/ $10.3168 /$ jds.2016-12067.

Bruno, J., A. Nicolas, S. Pesenti, J. Schwarz, J.-L. Simon, J. Léonil, and P. Plaisancié. 2018. Corrigendum to "Variants of $\beta$-casofensin, a bioactive milk peptide, differently modulate the intestinal barrier: In vivo and ex vivo studies in rats." J. Dairy Sci. 101:5667. https://doi.org/10.3168/jds.2018-101-6-5666.

Caroli, A. M., S. Chessa, and G. J. Erhardt. 2009. Invited review: Milk protein polymorphisms in cattle: Effect on animal breeding and human nutrition. J. Dairy Sci. 92:5335-5352. https://doi.org/10 $.3168 /$ jds.2009-2461.

Chessa, S., O. Bulgari, and A. Caroli. 2018. Letter to the editor: About bovine $\beta$-casofensin genetic variants-A comment on Bruno et al. (2017). J. Dairy Sci. 101:4705. https://doi.org/10.3168/jds.2017 -14112 .

Farrell, H. M., Jr., R. Jimenez-Flores, G. T. Bleck, E. M. Brown, J. E. Butler, L. K. Creamer, C. L. Hicks, C. M. Hollar, K. F. Ng-KwaiHang, and H. E. Swaisgood. 2004. Nomenclature of the proteins of cows' milk - Sixth revision. J. Dairy Sci. 87:1641-1674. https://doi .org/10.3168/jds.S0022-0302(04)73319-6.

Gallinat, J. L., S. Qanbari, C. Drögemüller, E. C. G. Pimentel, G. Thaller, and J. Tetens. 2013. DNA-based identification of novel bovine casein gene variants. J. Dairy Sci. 96:699-709. https://doi .org/10.3168/jds.2012-5908.

Received January 10, 2018.

Accepted January 22, 2018.

${ }^{1}$ Corresponding author: pascale.plaisancie@inserm.fr 